\title{
AGING CHANGES IN LYMPHOPOIETIC AND MYELOPOIETIC ORGANS OF THE ANNUAL CYPRINODONT FISH, NOTHOBRANCHIUS GUENTHERI
}

\author{
E.L. Cooper, ${ }^{1}$ A. Zapata, $^{2}$ M. Garcia Barrutia ${ }^{2}$ and J.A. Ramirez ${ }^{3}$
}

(Received 15 March 1982)

\section{INTRODUCTION}

BIOLOGIC AGING has been analyzed from many different viewpoints (see review by Timiras, 1978). Some investigators (Burnet, 1959; Comfort, 1961, 1963; Walford, 1962) have discussed the possibility that aging may be an immunologic phenomenon, and recently Kay $(1978,1979)$ has stressed the importance of the thymus as a trigger for human aging. When considering comparative aging in primitive animals, some teleost fish have a relatively short lifespan (about one year), and they thus represent a choice model system for aging studies. Relevant studies using these fish have focused on at least three main parameters. First, there has been an emphasis on laboratory lifespans coupled with an analysis of certain age-associated pathologies (Comfort, 1960, 1963, 1964; Egami and Etoh, 1969; Liu and Walford, 1969; Markofsky and Milstoc, 1979a,b; Walford and Liu, 1965). Second, from a physiological viewpoint, the effects of parameters such as nutrition or hypothermia on fish lifespans have been investigated (Liu and Walford, 1966, 1975). Third, from a histologic viewpoint, morphological changes of various organs and their relationships with aging and sexual maturity have been described (Honma and Tamura, 1972; Tamura and Honma, 1969, 1973, 1974, 1977; Tamura, 1978).

Despite these necessary studies, there is still no systematic review of the relationships between observed changes in fish lymphohemopoietic organs and aging as one basis for the immunologic theory of aging. To begin an analysis of the relationship between aging and the immune system, we have analyzed the morphologic changes in lympho-myeloid organs of the East African annual fish, Nothobranchius guentheri and Cynolebias adloffi. We also emphasize the possible relationship between changes in the immune system and

\footnotetext{
${ }^{1}$ Correspondence should be addressed to E.L. Cooper at the Department of Anatomy, School of Medicine, University of California, Los Angeles, California 90024.

${ }^{2}$ Present address: Departamento de Citologia e Histologia, Facultad de Biologia, Universidad de Leon, Leon, Spain.

${ }^{3}$ Present address: Departmento de Immunologia, Escuela, Nacional de Ciencias Biologicas, Carpio y Plan de Ayala, Mexico 17 D.F., Mexico.
} 
appearance of tumors in aged fish. Although not proven, such an observation poses interesting relationships between aging, decline of the immune system, and the development of neoplasia and suggests a breakdown of immune surveillance.

\section{MATERIALS AND METHODS}

Fish used for study were Nothobranchius guentheri (class Pisces, family Cyprinodontidae) a small killifish from East Africa (Total 50). Some specimens of the South American annual fish, Cynolebias adloffi, were also examined. The fish were purchased commercially (Mr. R. Van Veen, Los Angeles, CA.), and maintained in our laboratory at $22^{\circ} \mathrm{C}$ with a 12 hour light/dark photoperiod and a diet of live adult Artemia salina supplemented with frozen homogenized beef heart. The fish ( 5 per each period) were killed at 2 weeks, 1, 2, 4, 6, 8, 9, 10, 11 and 12 months, by immersion in toto in Bouin's fluid. Five fish of each stage were processed for routine light microscopy. Transverse sections of the entire fish body were prepared and stained with Masson's hemalum and picroindigo carime.

\section{RESULTS}

\section{Normal young immune system}

Before describing the histopathologic changes associated with aging of the immune system and the simultaneous appearance of numerous tumor cells in 12 month old fish, it is well to describe briefly the immune system as it appears normally. The peripheral blood contains all the leukocytic types which circulate freely. The main lympho-myeloid organs are the thymus, spleen and kidney (pro- and mesonephros). The thymus is situated in association with the branchial epithelium, usually at the junction of the operculum and the dorsal body musculature. It is surrounded by connective tissue, and by two months of age, shows a considerable increase in size (Fig. 1). The thymus is packed with thymocytes, but there was hardly any distinction between the cortex and medulla. The spleen is composed of lymphoid and erythroid elements, although the delineation into distinct white and red pulp is not sharp. As early as two weeks, the kidney shows accumulations of hemopoietic cells, increased activity that is quite pronounced at six months (Fig. 2). Since bone marrow is absent in fish, the kidney plays a major role in hemopoiesis.

The senescent immune system: changes in the thymus associated with increased tumor incidence

The earliest changes in the senescent immune system began to appear in the thymus at four months (Table 1). As in most other vertebrates, this was signaled by an increase in the amount of connective tissue elements. Increased connective tissue seemed first to affect the capsule and its extensions inward into the predominantly lymphoid parenchyma. Myoid cells also characterized the thymus at four months, although the presence of these peculiar muscle cells in primitive vertebrates (fish, amphibians, reptiles) is not necessarily associated with aging. By six months, the thymus showed an increase in the number of epithelial cysts and a decrease in lymphocytes.

At nine months, the thymus of Cynolebias adloffi showed essentially the same changes as in Nothobranchius guentheri up to six months, but this does not imply that the two fish age at the same rate. This probably reflects only the relative degrees of histopathologic changes that occur from normal to total senescence up to the 12 -month period. By 12 months, several fish, especially Nothobranchius, had thymuses that were completely degenerated when compared with the condition in two-month-old fish (Fig. 3). There were less lymphocytes whose appearance was masked by massive amounts of connective tissue. 


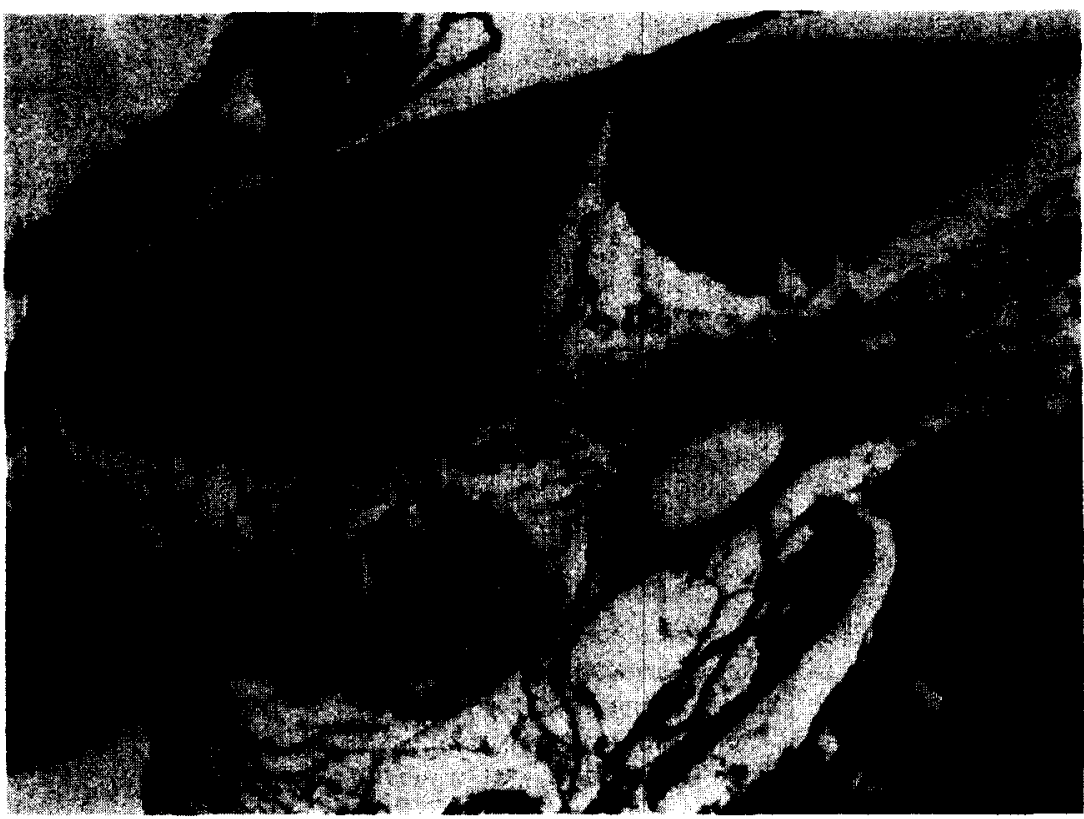

FIa. 1. The thymus showing dense accumulations of thymocytes is located in association with the branchial epithelium usually at the junction of the operculum and the dorsal body musculature. ( $x$ 16)

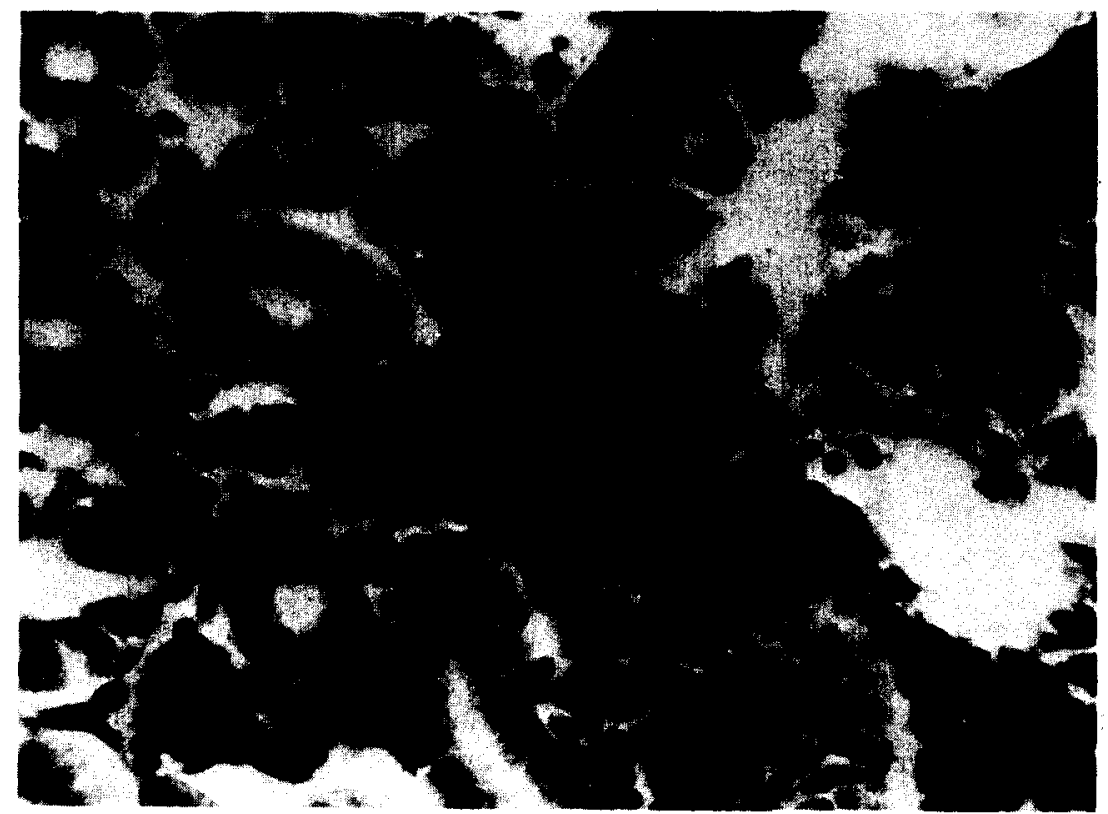

Fic. 2. The kidney showing well-defined tubules with increased hemopoietic activity apparent as numerous cells with darkened nuclei. $(x 40)$ 
TABle 1. TUMOR INCIDENCE IN RELATION TO AGE AND SENESCENT CHANGES OF THE THYMUS IN Cynolebias adloffi AND Nothobranchius guentheri

\begin{tabular}{|c|c|c|c|}
\hline $\begin{array}{l}\text { Age of fish (in months) when } \\
\text { analyzed for histopathologic } \\
\text { alterations; total fish-50; } 5 \text { per } \\
\text { observation period }\end{array}$ & $\begin{array}{l}\text { Condition of spleen, } \\
\text { kidney, liver }\end{array}$ & Condition of thymus & $\begin{array}{l}\text { Tumor incidence } \\
(+=100 \% ;-0 \%)\end{array}$ \\
\hline 0.5 & $\begin{array}{l}\text { kidney-hemopoietic; } \\
\text { spleen-hemopoietic }\end{array}$ & highly lymphopoietic & - \\
\hline 1 & $\begin{array}{l}\text { kidney-hemopoietic; } \\
\text { spleen hemopoietic }\end{array}$ & highly lymphopoietic & - \\
\hline 2 & $\begin{array}{l}\text { kidney-hemopoietic; } \\
\text { spleen-hemopoietic }\end{array}$ & highly lymphopoietic & - \\
\hline 4 & $\begin{array}{l}\text { kidney-hemopoietic; } \\
\text { spleen-hemopoietic }\end{array}$ & $\begin{array}{l}\text { earliest senescent } \\
\text { changes; increased } \\
\text { connective tissue; } \\
\text { myoid cells }\end{array}$ & - \\
\hline 6 & $\begin{array}{l}\text { kidney-hemopoietic; } \\
\text { spleen-hemopoietic }\end{array}$ & $\begin{array}{l}\text { increase in epithelial } \\
\text { cysts }\end{array}$ & - \\
\hline 8 & $\begin{array}{l}\text { kidney-hemopoietic; } \\
\text { spleen-hemopoietic }\end{array}$ & $\begin{array}{l}\text { increase in epithelial } \\
\text { cysts }\end{array}$ & - \\
\hline 9 & $\begin{array}{l}\text { kidney-hemopoietic; } \\
\text { spleen-hemopoietic }\end{array}$ & $\begin{array}{l}\text { increase in epithelial } \\
\text { cysts }\end{array}$ & - \\
\hline 10 & $\begin{array}{l}\text { kidney-hemopoietic; } \\
\text { spleen-hemopoietic }\end{array}$ & $\begin{array}{l}\text { increase in epithelial } \\
\text { cysts }\end{array}$ & - \\
\hline 11 & $\begin{array}{l}\text { kidney-hemopoietic; } \\
\text { spleen-hemopoietic }\end{array}$ & $\begin{array}{l}\text { increase in epithelial } \\
\text { cysts }\end{array}$ & - \\
\hline 12 & $\begin{array}{l}\text { Marked tumorous growth } \\
\text { in kidney and liver. } \\
\text { Tentative classification } \\
\text { in kidney: histiocytic } \\
\text { lymphoma }\end{array}$ & $\begin{array}{l}\text { Total degeneration } \\
\text { essentially devoid } \\
\text { of lymphocytes }\end{array}$ & $\begin{array}{l}\quad+ \\
\text { Marked tumorous } \\
\text { growth in oral } \\
\text { cavity, connective } \\
\text { tissue }\end{array}$ \\
\hline
\end{tabular}

During the 12-month observation period characterized by beginning and total subsequent degeneration of the thymus, the rest of the tissues and organs were essentially normal in appearance. These tissues and organs included connective tissue, heart, liver, small intestine, testes and gas bladder, and up to six months there was no evidence of tumors.

In contrast, at the time when the thymus showed its greatest senescence at 12 months, there were marked tumorous growths apparent in the oral cavity, connective tissue, kidney and liver. The kidney and liver showed the most pronounced changes. In its normal state, the kidney is composed of rather closely aggregated tubules between which are interspersed hemopoietic cells, often consisting of many lymphocytes. At 12 months, the tubules appeared to be few and were abnormally displaced by massive accumulations of tumor cells (Fig. 4). These tumor cell masses were circumscribed, well-delineated, and usually consisted of a core of large, faintly staining cells. The nuclei were also large and showed pronounced nucleoli and thin threads of chromatin. Pyknotic nuclei were also numerous (Fig. 5). The liver showed a rather similar histopathology. Although characterized by evenly distributed cords of hepatocytes in the normal condition, the tumorous intrusions appeared as circumscribed masses which nearly obliterated the few remaining parenchymal components (Figs. 6, 7). 


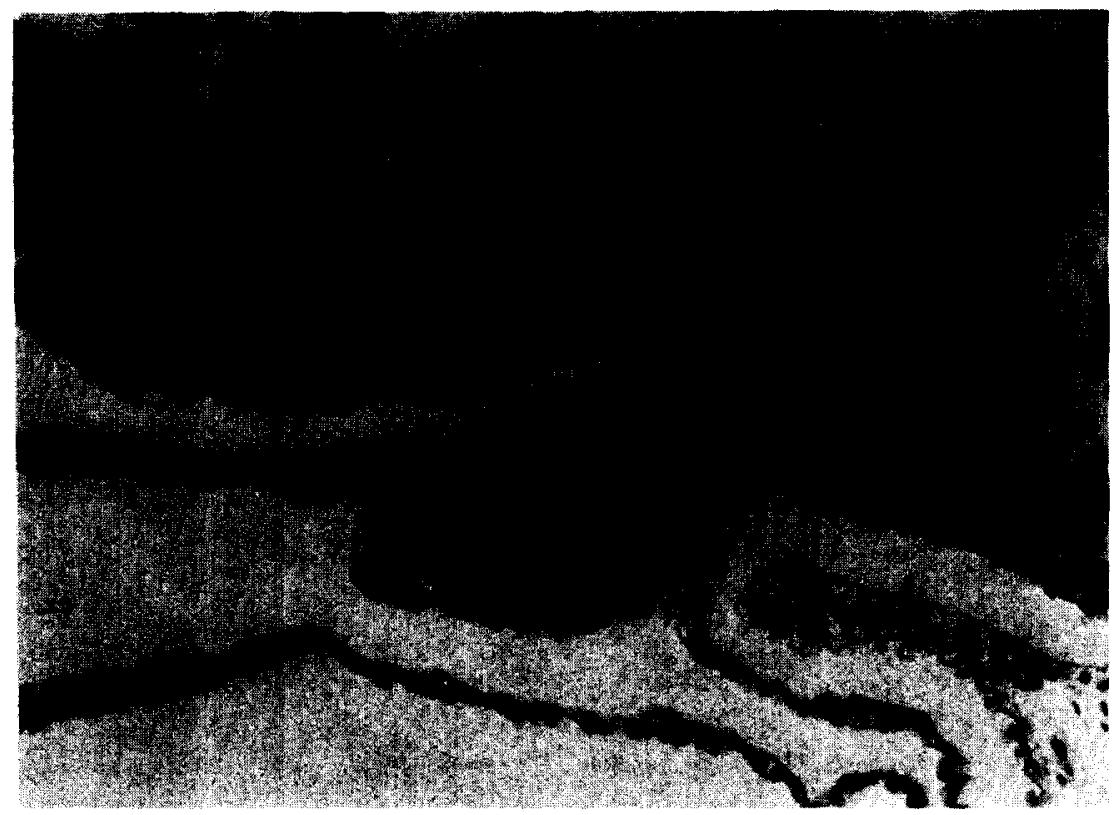

Fig. 3. The thymus at 12 months of Nothobranchius showing complete degeneration characterized by few thymocytes. $(\times 16)$

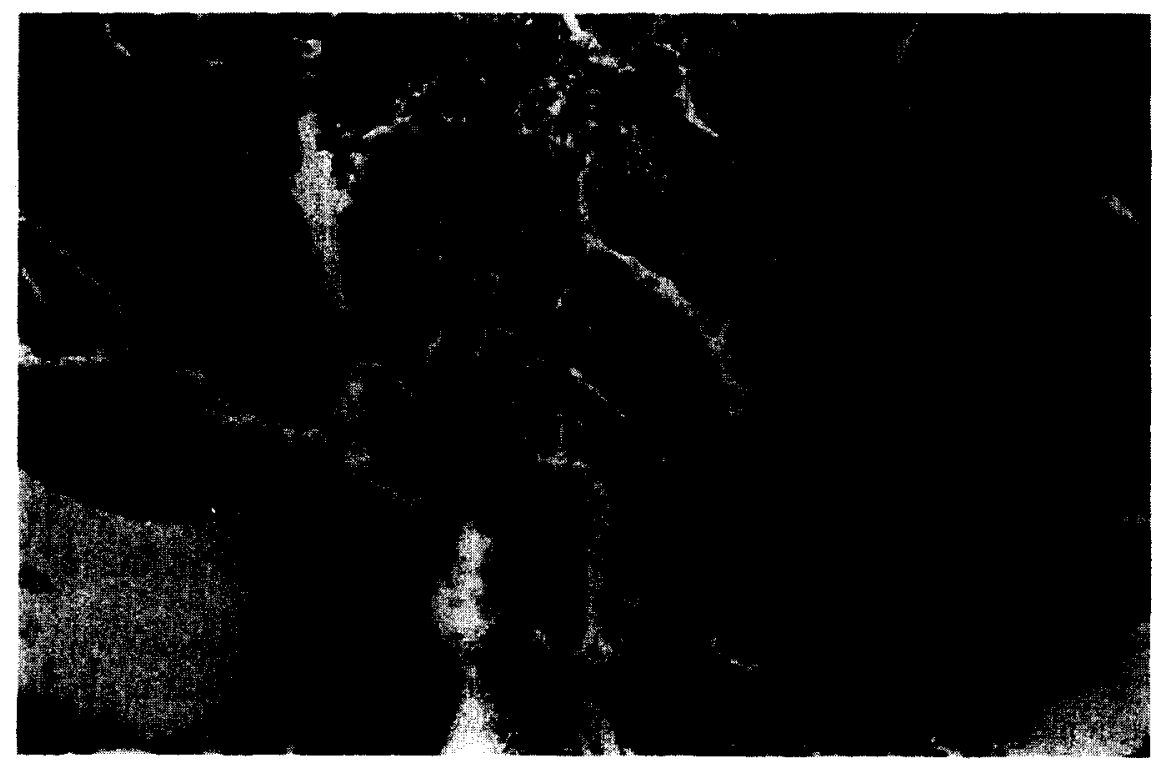

Fio. 4. Kidney at 12 months, showing displacement of closely aggregated tubules by massive accumulations of tumor cells. $(\times 6.5)$ 


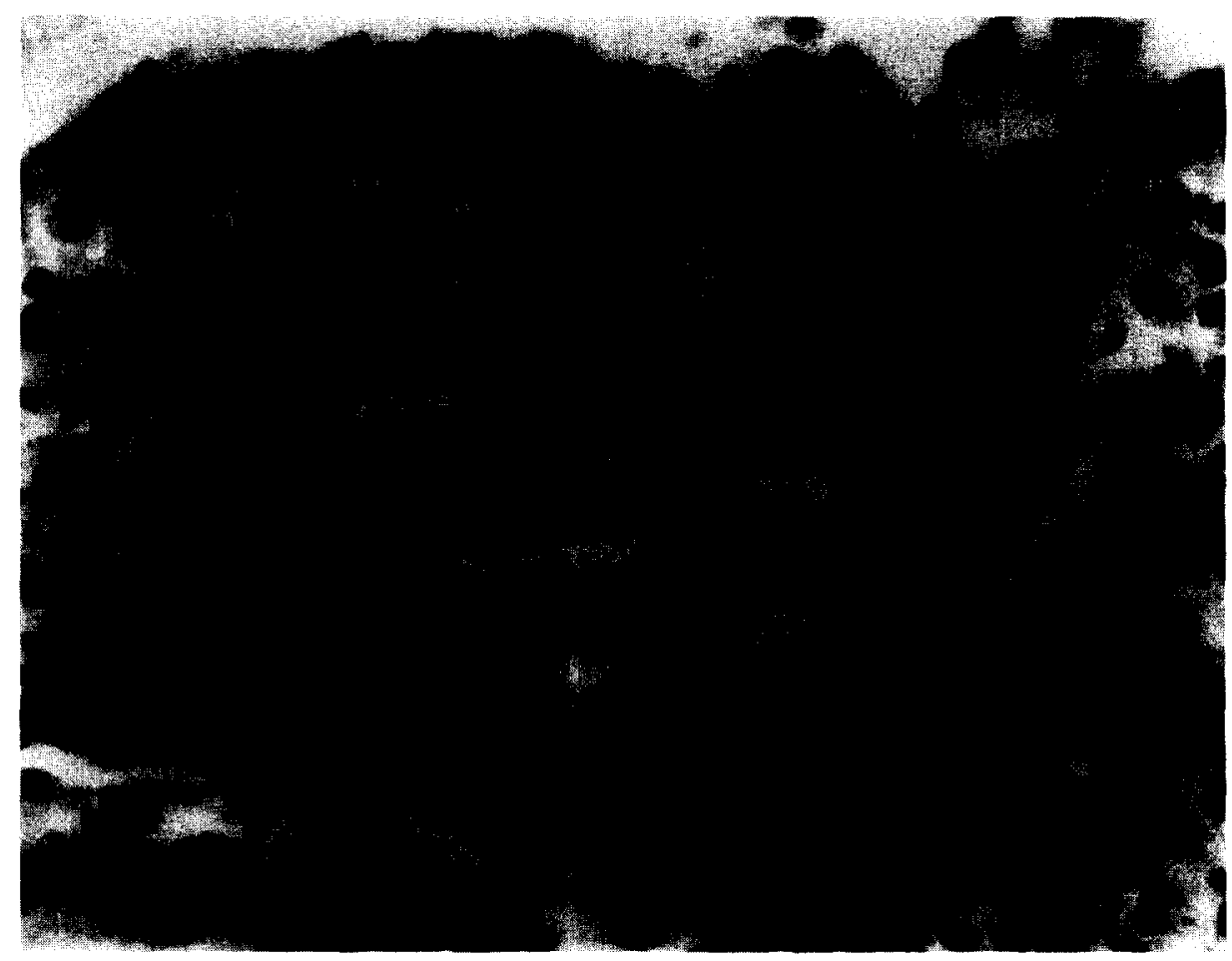

FIG. 5. Tumor-cell mass from the kidney which is well circumscribed and delineated. Note the core of large cells with faintly staining nuclei as well as numerous pyknotic nuclei. $(\times 40)$

\section{DISCUSSION}

In search of newer and more unique animal models to study aging, with special emphasis on the immune system, investigators are turning to invertebrates and to fish, amphibians, and reptiles (Cooper and Walford, 1982). Invertebrates and fish constitute the two major phylogenetic groups in which most of the work on comparative gerontology has been performed (Cooper, 1979). Fish as vertebrates, with simpler but similar cell and organ systems to humans thus provide models that can answer questions of direct bearing on the problem of senescence in humans. For example, the immune system of fish consists of leukocytes in the circulating blood, the thymus, spleen and the kidney, and it is known that fish are capable of both cellular and humoral immune responses (Cooper, 1976). Thus it is becoming generally accepted that fish possess the equivalent of functional $T$ and B lymphocytes, an immune system essentially like that of mammals (Van Muiswinkel and Cooper, 1981).

During the early 1960s, Walford (1964) advanced his immunologic theory of aging, suggesting that the existence of age-related immunologic disharmony was probably autoimmune in nature. According to this view, immunologic responses represent the cause of aging in contrast to the view of those who propose that changes in the immune system are a consequence of aging. In both instances, however, the degree of immunologic competence at various ages in the life cycle are related to overall physiologic homeostasis, and 


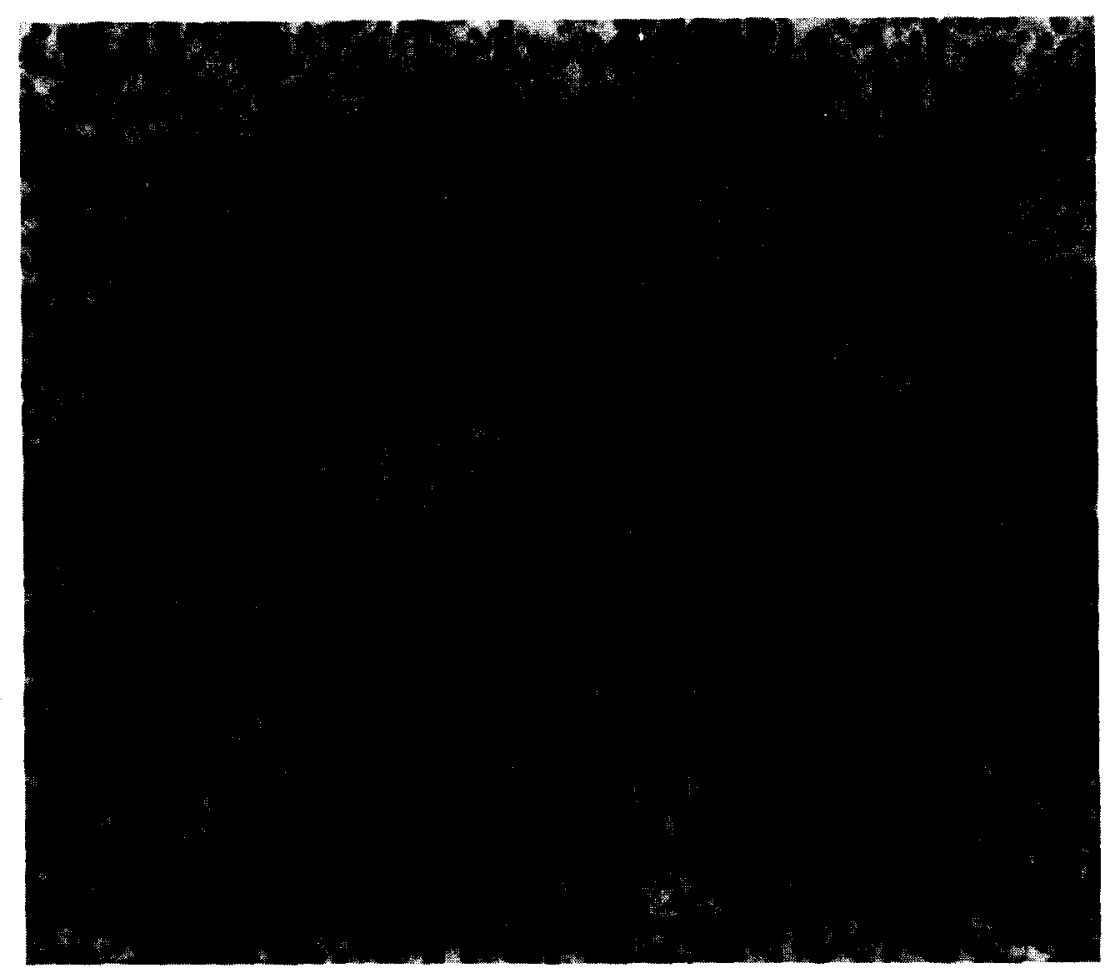

FIG. 6. The liver showing only a few cords of normal hepatocytes. Otherwise the entire organ consists of tumors which are well circumscribed masses. $(\times 16)$

any changes or disharmony will certainly affect adaptation and survival (Timiras, 1978). In support of the second view, Kay (1979) has stressed that certain immune functions tend normally to decline with age in at least six mammalian species and in humans. Furthermore, she has shown that as immunologic vigor decreases, the incidence of auto-immune immune-complex diseases and cancer increases. Emphasizing one aspect of the immune system (that mediated by $\mathrm{T}$ lymphocytes), she presents earlier evidence that restoration to normality (or reversal of these deficiencies) can be accomplished by reconstituting immunologically deficient animals with young, but not old, syngeneic thymus or spleen grafts (Fabris, 1977; Piantanelli and Fabris, 1977; Kay, 1979). Thus, the evidence is clear that in mammals, T-lymphocyte function declines with age.

In this present work, we have pointed out for the first time the marked senescent changes that occur in the thymus of fish. These histopathologic changes are strikingly similar to those that occur in mammals and that have been reported in another teleost, the mouth breeder (Sailendri, 1973) and in an amphibian, the bullfrog (Cooper, 1967). The unique feature of our histopathologic analysis in $N$. guentheri and $C$. adloffi is that as the thymus undergoes senescence, there is an increase in all fish in age-associated pathologic changes such as cancer at the maximum period of 12 months.

Thus we have extended the pioneer work by Walford and Liu (1965) on the histopathologic changes of organs other than the thymus. Moreover, we have confirmed 


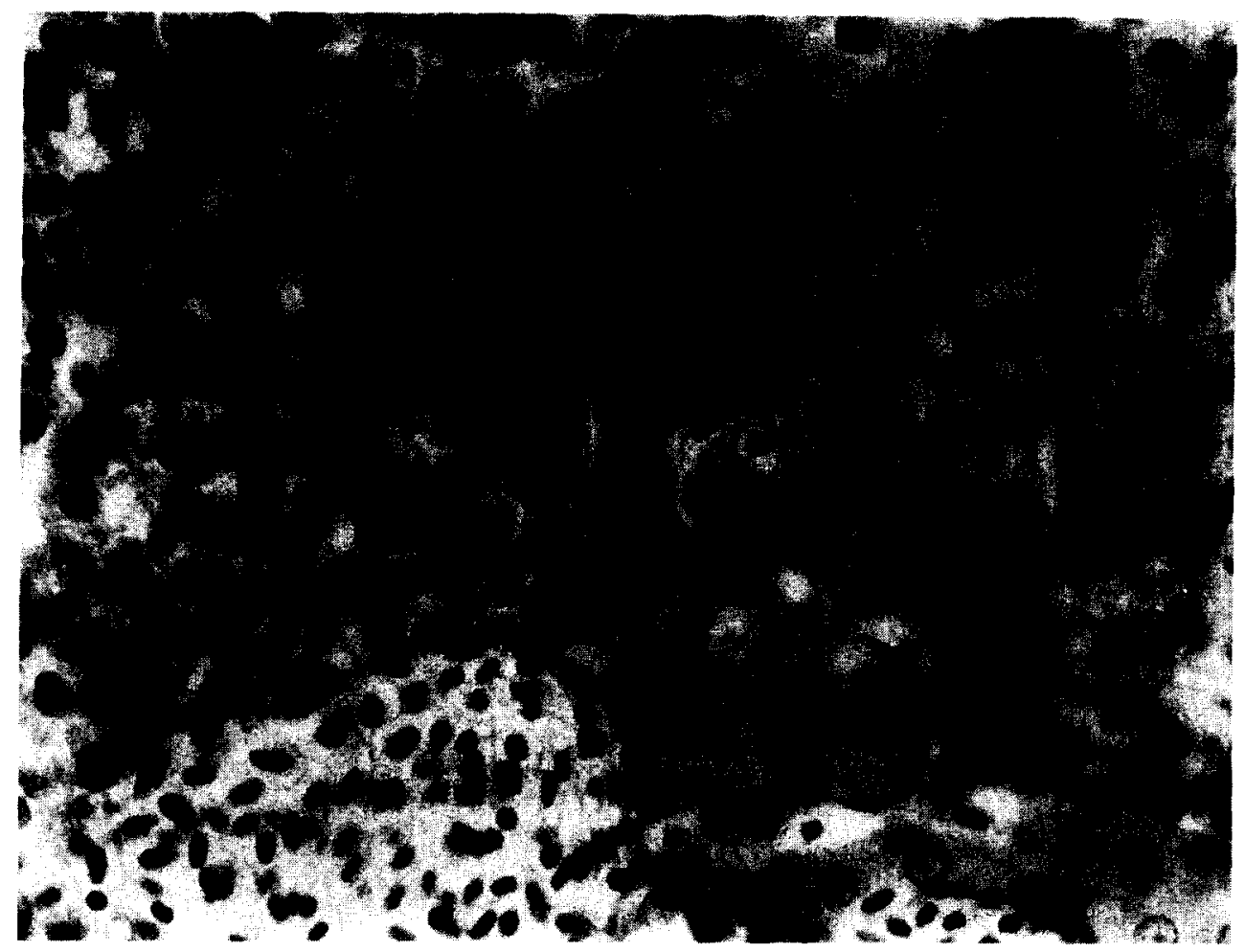

Fig. 7. A few normal hepatocytes are located in the center squeezed on both the left and right sides by wellcircumscribed masses of tumor cells. $(\times 40)$

the observations of Markofsky and Milstoc $(1979 a, b)$ that significant aspects of the senescent changes in the kidney and liver of $N$. guentheri involved malignant transformation where, in the kidney, it was referred to as nodular type histiocytic lymphoma. The cancer was characterized by increased numbers of large cells within a multicentric nodular aggregation. The cells were irregular in size and shape, with a pale pinkish, ill-defined cytoplasm which of ten contained lipochrome pigment. Often these cells were surrounded by small lymphocytes which, of course, showed greater cytoplasmic basophilia and pyknotic nuclei.

Since the thymus is the source of $\mathrm{T}$ lymphocytes in vertebrates, the obvious question remaining from our histopathologic analysis of thymus degeneration during senescence in fish is: how can these animals best serve as unique models for understanding the intrinsic or extrinsic causes of senescence? Obviously, there are two points that are clear. First, there is an increase in certain diseases as the immune system declines, and, obviously, there is an increase in life expectancy as in humans. Thus, understanding the aging immune system is of prime importance from the biological viewpoint since there are these analogies that are comparable. Fish are certainly useful in the more pragmatic sense for what they may offer relevant to clarifying senescence in humans. Second, fish may offer a reason unique to them which will be defined later. According to Kay (1979), future studies should be directed toward understanding the processes that regulate growth and atrophy 
of the thymus, concentrating on the neuroendocrine thymic axis. In this regard, fish are unique, providing models for examining the role of seasons of the year, light and nutrition on immune function.

It is known, for example, that in the Japanese annual fish, the ayu and the ice-goby, the greatest volume of the thymus occurs in June and July (see review by Tamura, 1978). The thymus undergoes a remarkable involution prior to degeneration of the lymphoid organs, spleen and kidney (head, anterior or pronephros) at sexual maturation; and this was also observed in the mature chum salmon during its spawning migration. In other experiments, short photoperiods caused involution of the thymus which paralleled sexual maturation of the fish one to two months earlier than in control groups if the ayu were reared in outdoor hatchery ponds. In contrast, regressive changes in the thymus and sexual maturation of the ayu occurred during long photoperiods, but one to two months later than in controls. These represent but two examples of the pronounced relationship that must exist between the thymus and the neuroendocrine system. Fish will prove to be fascinating in dissecting these interactions, with more precision, in the future.

\section{SUMMARY}

The thymus of aging annual, cyprinodont fish, Nothobranchius guentheri and Cynolebias adloffi begins to undergo senescent changes at approximately four months. At this time, the histopathology reveals increased amounts of connective tissue, epithelial cysts and myoid cells, but decreased numbers of thymocytes. At 12 months, of the 50 fish observed at 10 stages from day 15 and $1,2,4,6,8,9,10,11,12$ months the maximum time of senescence, there was an increased incidence of tumors in the oral cavity, connective tissue, kidney and liver in all 5 fish. At least in the kidney, the malignant transformation was classified as nodular-type histiocytic lymphoma. It is of interest that development of these tumors occurs during peak senescent changes in the thymus, supporting the view that as fish age, accompanied by atrophy of the thymus, the immune system is less vigorous and there is an increase in the incidence of cancer.

Acknowledgments - We acknowledge Mr. R. Van Veen of Los Angeles who supplied the fish. This investigation was supported in part by research grants HD 09333-07 from NIH to ELC; Postdoctoral Grant, Education and Science Minister SPAIN (AZ); COFAA-IPN Grant, Mexico (JAR).

\section{REFERENCES}

Burnet, F.M. (1959) Brit. Med. J. 2, 720.

Comfort, A. (1960) Gerontologia 4, 177.

Comfort, А. (1961) Am. Heart J. 62, 293.

Comfort, A. (1963a) Lancet 2, 138.

COMfort, A. (1963b) Gerontologia 8, 150.

Comfort, A. (1964) Aging: the Biology of Senescence, 365 pp., Routledge and Kegan Paul, London.

COOPER, E.L. (1967) J. Morphol. 122, 381.

Cooper, E.L. (1976) Comparative Immunology, 338 pp., Prentice Hall, Englewood Cliffs, N.J.

Cooper, E.L. (1979) Task Force Report, Nat. Inst. Aging, Bethesda, MD.

COOPER, E.L. (1980) Proc. Ist Congr., Developmental and Comparative Immunology, Aberdeen, Scotland.

CoOPer, E.L. and Walford, R.L. (1982) Dev. Comp. Immunol. 6, 391.

Egami, N. and EтoH, H. (1969) Exp. Geront. 4, 127.

Fabris, N. (1977) Hormones and Aging, Immunology and Aging, Plenum Press, N. Y., p. 73.

Honma, Y. and Tamura, E. (1972) Bull. Jpn. Soc. Sci. Fish 38, 995. 
Kay, M.M.B. (1978) Fed. Proc. 37, 1241.

KAY, M.M.B. (1979) J. Invest. Dermatol. 73, 29.

LIU, R.K. and WALFORD, R.L. (1965) Nature 212, 1277.

LIU, R.K. and WALFORD, R.L. (1969) Zoologica 54, 1.

LiU, R.K. and WALford, R.L. (1975) J. Gerontol. 30, 129.

Markofsky, J. and Mustoc, M. (1979a) Exp. Geront. 14, 11.

Markofsky, J. and Milstoc, M. (1979b) Exp. Geront. 14, 149.

Piantanelli, L. and Fabris, N. (1977) Hypopituitary Dwarf and Athymic Nude Mice and the Study of the Relationships among Thymus, Hormones, and Aging, Alan R. Liss, N.Y., p. 315.

SAILENDRI, K. (1973) Ph.D. Thesis, Madurai Univ. of India.

Tamura, E. (1978) Special Publication, The Sado Marine Biol. Station, Nitgata Univ. Ser. 1., 73.

TAmura, E. and Honma, Y. (1969) Bull. Jpn. Soc. Sci. Fish 36, 661.

Tamura, E. and Honma, Y. (1973) Bull. Jpn. Soc. Sci. Fish 39, 1003.

Tamura, E. and Honma, Y. (1974) Bull. Jpn. Soc. Sci. Fish 41, 413.

Tamura, E. and Honma, Y. (1977) Bull. Jpn. Soc. Sci. Fish 43, 963.

Timiras, P.A. (1978) Am. Sci. 66, 604.

Van Muiswinkel, W.B. and CoOPER, E.L. (Editors) Dev. Comp. Immunol. 6, Suppl. 2, 1982.

WALFORD, R.L. (1962). J. Gerontol. 17, 281.

WALFORD, R.L. (1964) The Gerontologist 4, 195.

WALFORD, R.L. and LuU, R.K. (1965) Exp. Geront. 1, 161. 